\title{
SENSITIVITY OF ODONATE NYMPHS TO DIFFERENT CLASSES OF AGRICULTURAL INSECTICIDES, FREQUENTLY APPLIED IN SWAT VALLEY PAKISTAN
}

\author{
ILAHI, I. ${ }^{* 1}$ - YOUSAFZAI, A. M. ${ }^{2}$ - RAHIM, A. ${ }^{1}-$ HAQ, T. U. ${ }^{3}-$ WAHAB, S. $^{1}-$ ALI, H. ${ }^{1}-$ HALIMULLAH $^{1}-$ \\ FAROOQ, M. ${ }^{1}$ - MUHAMMAD, H. ${ }^{1}$ - Ullah, F. ${ }^{1}$ - AhMAD, B. ${ }^{1}$ - Ullah, S. ${ }^{4}-$ HuSSAIN, S. ${ }^{1}$ \\ ${ }^{I}$ Department of Zoology, University of Malakand \\ Chakdara, Dir Lower, Khyber Pakhtunkhwa, Pakistan \\ ${ }^{2}$ Department of Zoology, Islamia College Peshawar \\ Peshawar, Khyber Pakhtunkhwa, Pakistan \\ ${ }^{3}$ Department of Biotechnology, University of Malakand \\ Chakdara, Dir Lower, Khyber Pakhtunkhwa, Pakistan \\ ${ }^{4}$ Department of Botany, University of Malakand \\ Chakdara, Dir Lower, Khyber Pakhtunkhwa, Pakistan \\ ${ }^{*}$ Corresponding author \\ e-mail: ikramilahi@uom.edu.pk \\ (Received $7^{\text {th }}$ Feb 2019; accepted $1^{\text {st }}$ May 2019)
}

\begin{abstract}
The sensitivity of blue-tailed damselfly (Ischnura elegans) and crimson marsh glider dragonfly (Trithemis aurora) nymphs to six different insecticides were studied during 48-hour exposure in the laboratory conditions. Lambda cyhalthrin was found to be the most toxic. Chlorpyrifos was found least toxic. The highest concentrations of deltamethrin, cypermethrin, lambdacyhalothrin, chlorpyrifos, dichlorvos and acetamiprid that caused no mortality of I. elegans were $0.0078,0.0039,0.00048,0.0078,0.0039$ and $0.00195 \mathrm{ppm}$, respectively. The highest concentrations of deltamethrin, cypermethrin, lambdacyhalothrin, chlorpyrifos, dichlorvos and acetamiprid that caused no mortality of T. aurora were $0.0039,0.00195,0.00048,0.0156,0.0078$ and 0.000975 ppm, respectively. The lowest concentrations of deltamethrin, cypermethrin, lambdacyhalothrin, chlorpyrifos, dichlorvos and acetamiprid that caused $100 \%$ mortality of I. elegans were $0.5,0.5,0.0156,1.0,0.5$ and $0.25 \mathrm{ppm}$, respectively. The lowest concentrations of deltamethrin, cypermethrin, lambdacyhalothrin, chlorpyrifos, dichlorvos and acetamiprid that caused $100 \%$ mortality of T. aurora were $0.25,0.25,0.0312,2,1$ and $0.125 \mathrm{ppm}$, respectively. Significantly $(\mathrm{P}<0.05)$ lowest $\mathrm{LC}_{90}$ values were observed for lambda cyhalothrin (LC90 against $I$. elegans $=0.01 \mathrm{ppm}, \mathrm{LC} 90$ against $T$. aurora $=0.018 \mathrm{ppm})$. Next to the lambda cyhalothrin, significantly $(\mathrm{P}<0.05)$ lowest $\mathrm{LC}_{90}$ values were observed for acetamiprid ( $\mathrm{LC}_{90}$ against $I$. elegans $=0.122 \mathrm{ppm}, \mathrm{LC}_{90}$ against $T$. aurora $=$ $0.093 \mathrm{ppm}$ ). From the findings of the present study, it was concluded that I. elegans and T. aurora nymphs are highly sensitive to lambda cyhalothrin and acetamiprid.
\end{abstract}

Keywords: deltamethrin, cypermethrin, lambda cyhalothrin, chlorpyrifos, dichlorvos, acetamiprid

\section{Introduction}

Damselfly (order Odonata, sub order Zygoptera) and dragonfly (order Odonata, sub order Anisoptera) nymphs are well known predators of mosquito larvae that play important role in the natural regulation of mosquito population (Boyd, 2005; Din et al., 2013). Odonate nymphs are very useful biological control agent against mosquitoes (Mitra, 2006). Odonate nymphs face environmental pressure due to increasing pollutants in their habitats. Aquatic habitats are contaminated with agricultural insecticides as a result of spray drift or runoff (Armbrust and Peeler, 2002; Hilz and Vermeer, 2012). Aquatic insects are very sensitive to insecticides (Mokry and Hoagland, 1990; Mian and Mulla, 1992). 
Insecticides are the agents applied for the control of insect pests. They are generally called adulticides, ovicides, pupicides and larvicides. Insecticides may be synthetic chemicals or derived from plants. Insecticides which are derived from plants are also called botanical insecticides. Alkaloids, pyrethrins, rotenone, rotenoids and neem are the known botanical insecticides. Some synthetic chemical insecticides have been modeled after natural botanical insecticides. For example nicotinoids or neonicotinoids such as imidacloprid, acetamiprid etc. are the synthetic chemical insecticides modeled on plant nicotine, while pyrethroids such deltamethrin, lambda cyhalothrin, cypermethrin etc. have been modeled on plant pyrethrins (Gullan and Cranston, 2005). Carbamates (e.g. carbofuran, carbaryl etc.), organochlorines (DDT, endosulfan, aldrin, dieldrin etc.) and organophosphates (e.g. dichlorovos, chloropyrifos, malathion etc.) are the synthetic chemical insecticides which are not modeled on botanical insecticides (Gullan and Cranston, 2005).

Organochlorine insecticides are highly toxic, bioaccumulative and persistent (Jayaraj et al., 2016). The vast application of organochlorines destroy both, pests and non-target organisms (Zacharia, 2011). After the application of organophosphates on target organisms, they can reach to the target pests, or reach surface water bodies and ground water; they can also contaminate the atmosphere or they can be ingested by non-target organisms. The chemical and physical characteristics, application methods and conditions of sites influence the destiny and effect of organophosphates (Lourencetti et al., 2008). Due to the frequent and excessive application of organophosphate pesticides and their slow decomposition rates, they accumulate in the soils and subsequently contaminate surface water bodies (Sirotkina et al., 2012). Chlorpyrifos which is an organophosphate, has been detected in arctic sea water and air (Vorkamp and Rigét, 2014). Some carbamates have also been detected in aquatic habitats (Tien et al., 2013). Herbicides compounds are also persistent in the soil from where they reach to the ground water and surface water bodies (Cai et al., 2004). It has been reported that the degradation of organochlorine herbicide compounds occur in soil due to light effect and microbial action (Fenoll et al., 2014). The presence of some of these herbicide compounds and their breakdown products have been detected in ground water and surface water bodies (Osano et al., 2002). Among the organochlorines, DDT (Dichloro diphenyltrichloroethane) played effective role in eradication of insect pests but on the other hand it has also damaged wild life and human health due to its persistence in the environment and bioaccumulation (Turusov et al., 2002; Jayaraj et al., 2016). Organophosphates, inhibitors of acetylcholinesterase, rapidly degrade by hydrolysis when exposed to water, soil, air and light, however their small amout have been detected in water and food (Jayaraj et al., 2016). They have been reported for their adverse effect on non-target aquatic organisms (Stenersen, 2004; Huynh and Nugegoda, 2012; Rubach et al., 2012). The insecticides of class pyrethroids are very effective against insect pests and they kill insect pests at low dose and are less bioavailable in the natural environment due to their strong absorptive characteristic and low water solubility (Davies, 1985). Pyrethroids inhibit ATPase enzymes that result in the disturbance of ionic balance which is the main toxic effect of pyrethroids (Coats et al., 1989). Pyrethroids are highly toxic for aquatic insects, aquatic crustaceans and fish (Mian and Mulla, 1992; Werner and Moran, 2008). Neonicotinoid cause toxic effects on insets by acting directly on the nicotinic acetylcholine receptors (nAChRs) (Nishiwaki et al., 2003; Casida and Durkin, 2013). There is emerging evidence about the adverse effect of neonicotinoids on nontarget organisms (Malev et al., 2012; Anderson et al., 2015; Morrissey et al., 2015).

To the author knowledge, very limited studies have been reported about the insecticides toxicity with odonate nymphs. For example, Beketov (2002) studied the comparative sensitivity of larvae of damselfly, dragonfly, mayfly and Daphnia magna to deltamethrin and 
esfenvalerate. They reported the deltamethrin 48-hour LC50 values of $0.0145 \mu \mathrm{g} / \mathrm{l}$ and 0.0760 $\mu \mathrm{g} / \mathrm{l}$ against nymphs of Lestes sponsa (damselfly) and Cordulia aenea (dragonfly), respectively. The LC50 values of deltamethrin against larvae of two species of mayflies, Cloeon dipterum and Caenis miliaria and larvae of Daphnia were $0.005 \mu \mathrm{g} / 1,0.0091 \mu \mathrm{g} / 1$ and $0.0293 \mu \mathrm{g} / \mathrm{l}$, respectively.

In Swat valley, Pakistan, insecticides are regularly applied in agricultural fields on peach orchards, vegetables and cereal crops for many years (Nafees et al., 2008; Nafees and Jan, 2009). The watershed of River Swat in Malakand Division, Pakistan, is called Swat Valley, which comprises of Swat, Malakand (Swat Ranizai Tehsil), and Chakdara (Adenzai Tehsil). Keeping in view, the impact of frequent application of insecticides on non-target organisms in the area, a laboratory study was conducted for the assessment of toxicity of agricultural insecticides to non-target aquatic insects, specifically native odonate nymphs, which are the predators of mosquito larvae.

\section{Materials and methods}

\section{Selection of insecticides for sensitivity study}

During the present study, the farmers who were cultivating vegetables and growing peach orchards in Swat, Pakistan, were interviewed about the type and brand of pesticides they apply on vegetables and fruit trees. Questionnaires were arranged for interview, in which the type, brand and frequency of application of pesticides were asked. The pesticide dealers at Matta bazar, Khwazakhela bazar, Mingora city, Shamozo bazar and Barikot bazar were also interviewed about the type and brand of pesticides they provide to the farmers. Six hundred farmers in Swat, Pakistan, were interviewed. The farmers were applying insecticide spray on tomato crops, three times from seedling to fruit ripening. They were applying insecticide spray on peach orchards, four times from before flowering to fruit ripening. Peaches are grown througout Swat Valley (Figure 1). According to the information obtained during interview, the main insecticides that the farmers apply are deltamethrin, cypermethrin, lambda cyhalothrin, chlorpyrifos, dichlorvos and acetamiprid. The details of manufacturer of these insecticides were also inquired. The farmers apply deltamethrin $(25 \% \mathrm{w} / \mathrm{w})$ of HERANBA Industries Limited India, cypermethrin (10\% w/v) of M/S Halex (M) SDN (BDH) Malaysia, lambda cyhalothrin $(2.5 \%$ w/v) of Jiangsu Fengshan Group Co. Ltd China, chloropyrifos $(40 \% \mathrm{w} / \mathrm{v})$ of M/S Halex (M) SDN (BDH) Malaysia, dichlorvos (100\% w/v) of Insecticides India Limited and acetamiprid (20\% w/w) of Jiangsu Fengshan Group Co. Ltd China. The reason of choice of insecticides of the above manufacturers by the farmers when inquired was the lower price. Table 1 shows the outcome of questionnaires.

\section{Collection of odonate nymphs}

Damselfly and dragonfly nymphs of 6 to 8 instars were collected from slow moving water on the bank of River swat near the Chirchil picquit at Chakdara, Dir Lower, Khyber Pakhtunkhwa, Pakistan. A rectangular plastic dipper $(38 \mathrm{~cm}$ length, $28 \mathrm{~cm}$ width and $6.5 \mathrm{~cm}$ height) was used as dipper during collection. The nymphs were brought to the laboratory in large plastic bottles along with water of collection site to the laboratory at University of Malakand, Khyber Pakhtunkhwa, Pakistan. In laboratory, the nymphs were maintained in small fish aquarium ( $45 \mathrm{~cm}$ length, $40 \mathrm{~cm}$ width and $40 \mathrm{~cm}$ height) in water of collection site. The laboratory was well ventilated and receiving sunlight through windows. Before starting experiment provided mosquito larvae as food. Proper literature was used the identification of 
specimens (Yousuf et al., 1996; Anjum, 1997; Mitra, 2002; Din et al., 2013). One species of blue-tailed damselfly, Ischnura elegans (Vander Linden, 1820) and one species of crimson marsh glider dragonfly namely, Trithemis aurora (Burmeister, 1839) were found in sufficient number; therefore, experiments were conducted on nymphs of these two species. The sensitivity of nymphs to the three classes of insecticides i.e., pyrethroids, organophosphates and neonicotinoids was studied in different times during May-September 2017. The maximum laboratory temperature was $29-33^{\circ} \mathrm{C}$ during experiments.

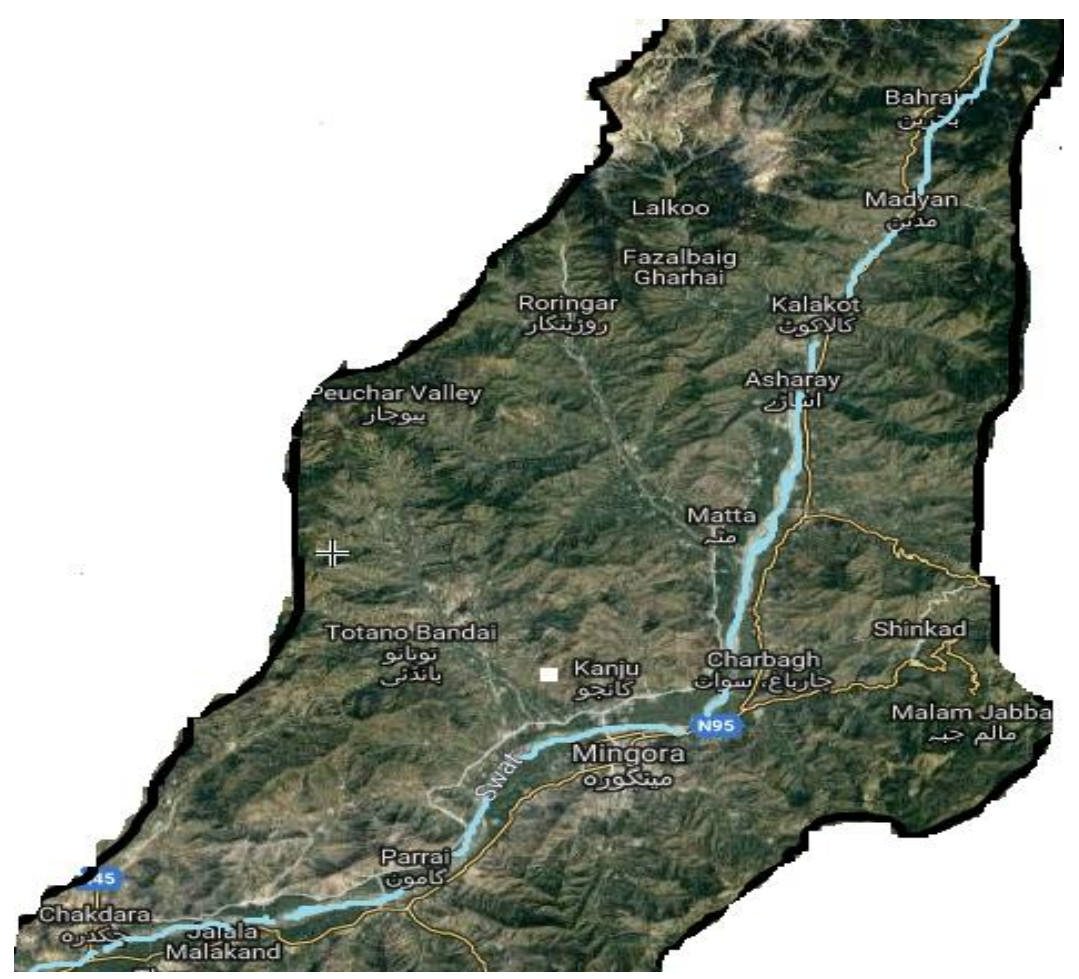

Figure 1. Figure derived from Google map showing watershed of River Swat in Malakand Division, Pakistan, where pesticides are applied on peach orchards. Latitude and Longitude: $34^{\circ} 49^{\prime} 19^{\prime \prime}$ North, $72^{\circ} 29^{\prime} 20^{\prime \prime}$ East. Blue line represents River Swat

Table 1. Types of insecticides applied on vegetables and peach orchards in Tehsil Matta District Swat

\begin{tabular}{c|c|c|c}
\hline Insecticides & Manufacturer & Number of Farmers & Farmers \% \\
\hline Deltamethrin & HERANBA Industries Ltd, India & 60 & 10 \\
Cypermethrin & M/S Halex (M) SDN (BDH), Malaysia & 90 & 15 \\
Lambda cyhalothrin & Jiangsu Fengshan Group Co. Ltd, China & 120 & 20 \\
Chlorpyrifos & M/S Halex (M) SDN (BDH), Malaysia & 120 & 20 \\
Dichlorvos & Insecticides India Limited & 90 & 15 \\
Acetamiprid & Jiangsu Fengshan Group Co. Ltd, China & 120 & 20 \\
Total & ------------------ & 600 & 100 \\
\hline
\end{tabular}

\section{Sensitivity of Odonate nymphs to pyrethroids}

The sensitivity of odonate (damselfly and dragonfly) nymphs to pyrethroids i.e., deltamethrin, cypermethrin and lambda cyhalothrin were studied during May-June 2017 (max temperature $29-33^{\circ} \mathrm{C}$ ). Initially range finding bioassay was conducted for finding 
concentration range of each pyrethroids for each odonate species, to be used for determining lethal concentrations ( $\mathrm{LC}_{50}$ and $\mathrm{LC}_{90}$ values) in definitive test. The ecological effects test guidelines of Environmental Protection Agency, USA (US EPA, 1996) for aquatic invertebrate acute toxicity test were followed for determining the concentration range. The following are the details.

\section{Solutions preparation}

Deltamethrin $(25 \% \mathrm{w} / \mathrm{w})$ of HERANBA Industries Limited, India, cypermethrin $(10 \% \mathrm{w} / \mathrm{v})$ of $\mathrm{M} / \mathrm{S}$ Halex (M) SDN (BDH), Malaysia and lambda cyhalothrin $(2.5 \% \mathrm{w} / \mathrm{v})$ of Jiangsu Fengshan Group Co. Ltd, China, were used. A $500 \mathrm{ml}$ stock solution of $100 \mathrm{ppm}$ of each insecticide was prepared in non-chlorinated tap water. Based on dilution equation $(\mathrm{C} 1 \mathrm{~V} 1=\mathrm{C} 2 \mathrm{~V} 2), 600 \mathrm{ml}$ test solution of $2 \mathrm{ppm}$ of each pyrethroid was prepared from the respective stock solution (of $100 \mathrm{ppm}$ ). The $2 \mathrm{ppm}$ solution of each pyrethroid was serially diluted by a factor of 2 and thus several dilutions of reducing concentrations were prepared in polyethylene containers $(400 \mathrm{ml}$ each). The detail of serial dilution of each pyrethroid was as under: From $600 \mathrm{ml}$ initial solution of $2 \mathrm{ppm}, 300 \mathrm{ml}$ solution was taken and put into $1000 \mathrm{ml}$ volumetric flask in which $300 \mathrm{ml}$ tap water was already added to make a $600 \mathrm{ml}$ solution of $1 \mathrm{ppm}$ (1/2 dilution). Again, from this solution, $300 \mathrm{ml}$ was taken and put into $1000 \mathrm{ml}$ volumetric flask in which $300 \mathrm{ml}$ tap water was already added to make a $600 \mathrm{ml}$ solution of $0.5 \mathrm{ppm}$ (1/4 dilution). Again, from this solution, $300 \mathrm{ml}$ was taken and put into $1000 \mathrm{ml}$ volumetric flask in which $300 \mathrm{ml}$ tap water was already added to make a $600 \mathrm{ml}$ solution of $0.25 \mathrm{ppm}$ (1/8 dilution). This serial dilution was continued till obtaining solution of $0.00195 \mathrm{ppm}$ (1/1024-fold). At each step, there was a 2-fold dilution in concentration, however volume of each dilution remained constant i.e. $300 \mathrm{ml}$. From the last dilution, $300 \mathrm{ml}$ solution was discarded so as to keep $300 \mathrm{ml}$ volume as in the previous dilutions. A total of 11 solutions of each pyrethroid were arranged. The 11 solutions were of the following concentrations: $2 \mathrm{ppm}, 1 \mathrm{ppm}$, $0.5 \mathrm{ppm}, 0.25 \mathrm{ppm}, 0.125 \mathrm{ppm}, 0.0625 \mathrm{ppm}, 0.03125 \mathrm{ppm}, 0.015625 \mathrm{ppm}, 0.0078125$, 0.003906 and $0.00195 \mathrm{ppm}$. The schematic for stock solutions preparation and serial dilution of pyrethroids is shown in Figure 2.

\begin{tabular}{|c|c|c|}
\hline Deltamethrin $25 \%$ w/w & Cypermethrin $10 \%$ w/v EC & Lambdacyhalothrin $2.5 \mathrm{w} / \mathrm{v}$ EC \\
\hline $200 \mathrm{mg}$ & $0.5 \mathrm{ml}$ & $2 \mathrm{ml}$ \\
\hline $500 \mathrm{ml}$ solution of $100 \mathrm{ppm}$ & $500 \mathrm{ml}$ solution of $100 \mathrm{ppm}$ & $500 \mathrm{ml}$ solution of $100 \mathrm{ppm}$ \\
\hline $12 \mathrm{ml}$ & $12 \mathrm{ml}$ & $12 \mathrm{ml}$ \\
\hline $\begin{array}{l}600 \mathrm{ml} \text { solution of } 2 \mathrm{ppm} \\
\text { which was serially diluted } \\
\text { till } 0.00195 \mathrm{ppm}\end{array}$ & $\begin{array}{l}600 \mathrm{ml} \text { solution of } 2 \mathrm{ppm} \\
\text { which was serially diluted till } \\
0.00195 \mathrm{ppm}\end{array}$ & $\begin{array}{l}600 \mathrm{ml} \text { solution of } 2 \mathrm{ppm} \\
\text { which was serially diluted } \\
\text { till } 0.00195 \mathrm{ppm}\end{array}$ \\
\hline
\end{tabular}

Figure 2. Schematic of stock solutions preparation and serial dilution of pyrethroids for toxicity study in odonate nymphs 


\section{Exposure of nymphs to pyrethroids for range finding}

The detail of procedure of range finding bioassay for each pyrethroid was as under: Eleven test solutions of $2,1,0.5,0.25,0.125,0.06250 .0315,0.0156,0.0078,0.0039$ and 0.00195 ppm concentrations of each pyrethroid were separately tested against nymphs of each odonate species in $400 \mathrm{ml}$ polyethylene containers. To each concentration of each pyrethroid, five nymphs of I. elegans were individually exposed in five polyethylene containers. To avoid cannibalism, nymphs were individually exposed to test solutions. The volume of test solution in each container was $250 \mathrm{ml}$. In addition, five nymphs were placed in five $400 \mathrm{ml}$ polyethylene control containers, each containing $250 \mathrm{ml}$ non-chlorinated tap water. In short, for testing each pyrethroid against I. elegans, 60 polyethylene cups (55 containers for 11 concentrations and 5 control containers) containing 60 nymphs were arranged. At the same time, the nymphs of $T$. aurora were also exposed to each pyrethroid. The detail of the exposure was the same as for I. elegans.

The period of exposure was 48 hours. Following standard toxicity protocols, the nymphs were not fed during the 48-hour exposure period (ASTM standard E47, 2008). After 48 hours of exposure period, the number of dead nymphs was noted. The criterion for death was lack of response to prodding. In case of lambda cyhalothrin, mortality was higher therefore further dilutions were made (diluted up to $0.00048 \mathrm{ppm}$ ) and tested.

The highest concentration of each pyrethroid that caused no mortality was noted for each odonate species. The concentration of each pyrethroid that caused lowest mortality was determined for each odonate species. Similarly, the lowest concentration of each pyrethroid that caused $100 \%$ mortality was also determined for each species. The schematic for range finding bioassay is shown in Figure 3.

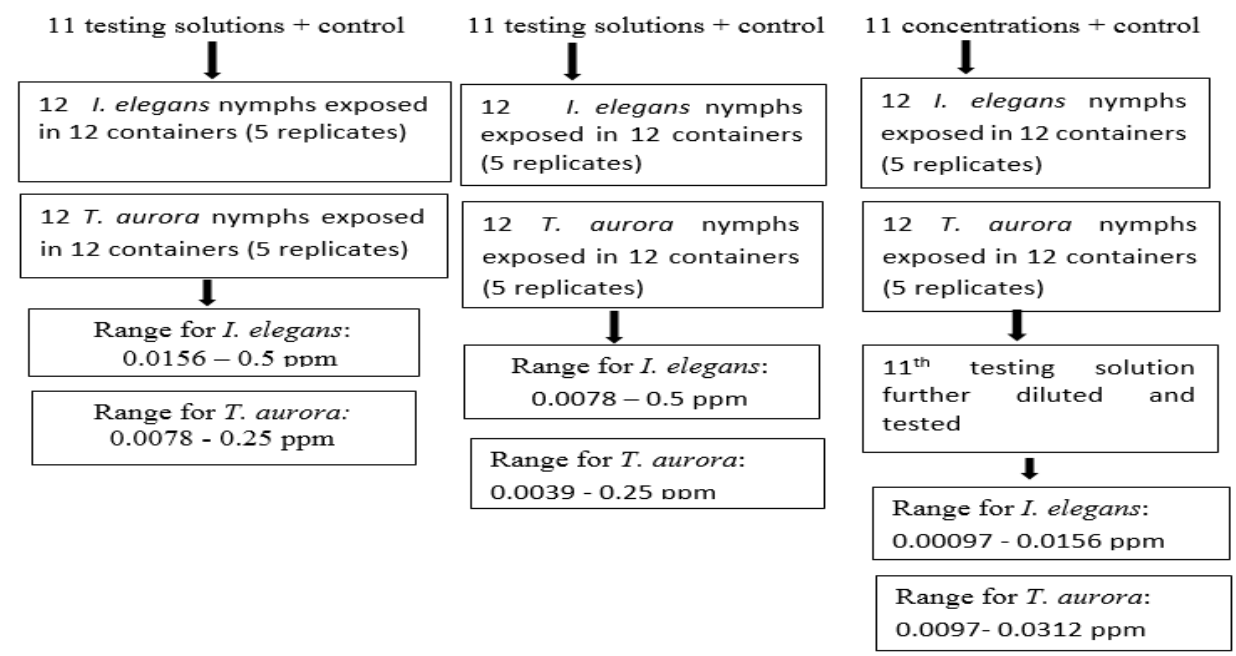

Figure 3. Schematic of range finding bioassay for determining the concentration ranges of pyrethroids during toxicity study in odonate nymphs

\section{Definitive test for determination of lethal concentrations of pyrethroids}

$\mathrm{LC}_{50}$ also called median lethal concentration is a measure of the lethal concentration of a toxin that kill $50 \%$ of the test population after exposure for a specified period. Lower $\mathrm{LC}_{50}$ values indicate higher toxicity of a toxin. During definitive test, $\mathrm{LC}_{50}$ value of each pyrethroid against nymphs of each odonate species was determined. For 
determination of $\mathrm{LC}_{50}$ values, nymphs of each odonate species were separately exposed to various concentrations of each pyrethroid within the concentration range determined during range finding bioassay. The schematic for definitive bioassay is shown in Figure 4 . The following are the details.

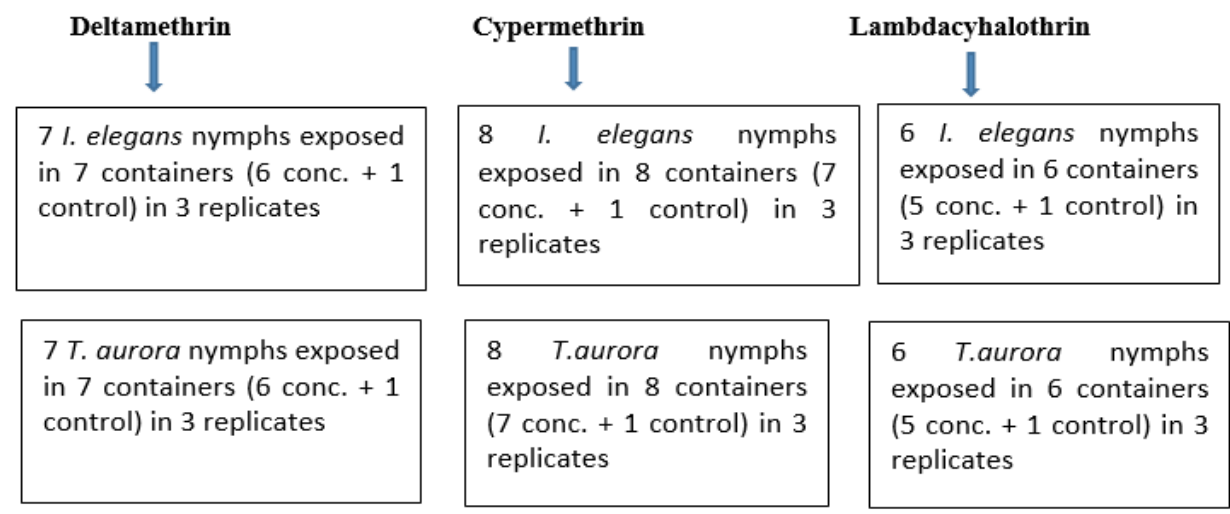

Figure 4. Schematic of experiment for determining $L C_{50}$ and $L C_{90}$ values of three pyrethroids against odonate nymphs

\section{Exposure to deltamethrin for determining $L_{50}$}

The concentrations of deltamethrin used against I. elegans were 0.0156, 0.03125, $0.0625,0.125,0.25$ and $0.5 \mathrm{ppm}$. Thus seven intact last instar nymphs of I. elegans were placed in seven polyethylene containers (six concentrations and one control). Similarly, the concentrations of deltamethrin used against $T$. aurora were $0.0078,0.0156,0.03125$, $0.0625,0.125$ and $0.25 \mathrm{ppm}$. In this case, seven intact last instar nymphs of T. aurora were placed in seven polyethylene containers (six concentrations and one control). The volume of each container was $400 \mathrm{ml}$ and testing solution was $250 \mathrm{ml}$. The control container was containing only 250 non-chlorinated tap water.

\section{Exposure to cypermethrin for determining $L C_{50}$}

The concentrations of cypermethrin used against I. elegans were 0.0078, 0.0156, $0.03125,0.0625,0.125,0.25$ and $0.5 \mathrm{ppm}$. Thus eight intact last instar nymphs of I. elegans were placed in eight polyethylene containers (seven concentrations and one control). The concentrations of cypermethrin used against T. aurora were 0.0039, $0.0078,0.0156,0.03125,0.0625,0.125$ and $0.25 \mathrm{ppm}$. Thus eight intact last instar nymphs of $T$. aurora were placed in seven polyethylene containers (seven concentrations and one control).

\section{Exposure to lambda cyhalothrin for determining $L C_{50}$}

The concentrations of lambda cyhalothrin used against I. elegans were 0.00097, $0.00195,0.0039,0.0078$ and $0.0156 \mathrm{ppm}$. Thus six intact last instar nymphs of I. elegans were placed in six polyethylene containers (five concentrations and one control). Similarly, the concentrations of lambda cyhalothrin used against $T$. aurora were $0.0097,0.00195,0.0039,0.0078,0.0156$ and $0.0312 \mathrm{ppm}$. Thus seven intact last instar nymphs of $T$. aurora were placed in seven polyethylene containers (six concentrations and one control). 


\section{Sensitivity of odonate nymphs to Organophosphates}

The sensitivity of odonate (damselfly and dragonfly) nymphs to organophosphates i.e., chlorpyrifos and dichlorvos was studied during July-August 2017 (max temperature $\left.28-32^{\circ} \mathrm{C}\right)$. Chloropyrifos $(40 \% \mathrm{w} / \mathrm{v})$ of M/S Halex (M) SDN (BDH), Malaysia and dichlorvos (100\% w/v) of Insecticides India Limited were used.

\section{Solutions preparation}

The detail of preparation of solutions of each organophosphate was the same as described for pyrethroid.

\section{Exposure of nymphs to organophosphates for range finding}

The procedure of bioassay for finding concentration ranges of two organophosphates (chlorpyrifos and dichlorvos) against odonate nymphs was the same as described for pyrethroids.

\section{Definitive test for determination of lethal concentrations of organophosphates}

During definitive test, $\mathrm{LC}_{50}$ and $\mathrm{LC}_{90}$ values of each organophosphate against each odonate nymph was determined. For determination of $\mathrm{LC}_{50}$ and $\mathrm{LC}_{90}$ values, nymphs of each odonate species were separately exposed to various concentrations of each organophosphate within the concentration range determined during range finding bioassay. The following are the details.

\section{Exposure to chlorpyrifos for determining $L C_{50}$}

The concentrations of chloropyrifos used against I. elegans were 0.0156, 0.03125, $0.0625,0.125,0.25,0.5$ and $1 \mathrm{ppm}$. Thus eight intact last instar nymphs of T. aurora were placed in eight polyethylene containers (seven concentrations and one control). Similarly, the concentrations of chloropyrifos used against T. aurora were 0.03125 , $0.0625,0.125,0.25,0.5,1$ and $2 \mathrm{ppm}$. Thus eight intact last instar nymphs of T. aurora were placed in eight polyethylene containers (seven concentrations and one control). The procedure of bioassay was the same as described for pyrethroids.

\section{Exposure to dichlorvos for determining $L_{50}$}

The concentrations of dichlorovos used against I. elegans were 0.0078, 0.0156, $0.03125,0.0625,0.125,0.25$ and $0.5 \mathrm{ppm}$. Thus eight intact last instar nymphs of T. aurora were placed in seven polyethylene containers (seven concentrations and one control). Similarly, the concentrations of dichlorovos used against $T$. aurora were $0.0156,0.03125,0.0625,0.125,0.25,0.5$ and $1 \mathrm{ppm}$. Thus eight intact last instar nymphs of $T$. aurora were placed in seven polyethylene containers (seven concentrations and one control). The procedure of bioassay was the same as described for pyrethroids.

\section{Sensitivity of odonate nymphs to neonicotinoid}

The sensitivity of odonate (damselfly and dragonfly) nymphs to neonicotinoid i.e., acetamiprid was studied during September 2017 ( $\max$ temperature $29-33^{\circ} \mathrm{C}$ ). Acetamiprid (20\% w/w) of Jiangsu Fengshan Group Co. Ltd, China was used. 


\section{Solutions preparation}

The detail of preparation of solutions of neonicotinoid (acetamiprid) was the same as described for pyrethroid.

\section{Exposure of nymphs to neonicotinoid (acetamiprid) for range finding}

The detail of bioassay for finding concentration range of neonicotinoid (acetamiprid) against odonate nymphs was the same as described for pyrethroids.

\section{Definitive test for determination of lethal concentrations of neonicotinoid (acetamiprid)}

During definitive test, $\mathrm{LC}_{50}$ and $\mathrm{LC}_{90}$ values of neonicotinoid (acetamiprid) against each odonate nymph was determined. For determination of $\mathrm{LC}_{50}$ and $\mathrm{LC}_{90}$ values, nymphs of each odonate species were separately exposed to various concentrations of neonicotinoid (acetamiprid) within the concentration range determined during range finding bioassay. The following are the details:

The concentrations of acetamiprid used against I. elegans were 0.0039, 0.0078, $0.0156,0.03125,0.0625,0.125$ and $0.25 \mathrm{ppm}$. Thus eight intact last instar nymphs of T. aurora were placed in seven polyethylene containers (seven concentrations and one control). Similarly, the concentrations of acetamiprid used against $T$. aurora were as $0.00195,0.0039,0.0078,0.0156,0.03125,0.0625$, and $0.125 \mathrm{ppm}$. Thus eight intact last instar nymphs of $T$. aurora were placed in seven polyethylene containers (seven concentrations and one control). The procedure of bioassay was the same as described for pyrethroids.

\section{Period of exposure and observations}

The period of exposure for each insecticide was 48 hours. Following standard toxicity protocols, the nymphs were not fed during the 48-hour exposure period (ASTM standard E47, 2008). After 48 hours of exposure period, the number of dead nymphs was noted. The criterion for death was lack of response to prodding. Experiment for each insecticide was run in triplicate. Several trips were conducted for collection of nymphs and experiments were repeated continuously till the number of nymphs in each replica of each concentration of each insecticide reached 20. In total 20 independent experiments were conducted for each insecticide (Figure 5). There occurred the death of only two nymphs in control containers during the whole experiments, indicating that conditions during each experiment were suitable and the nymphs were healthy.

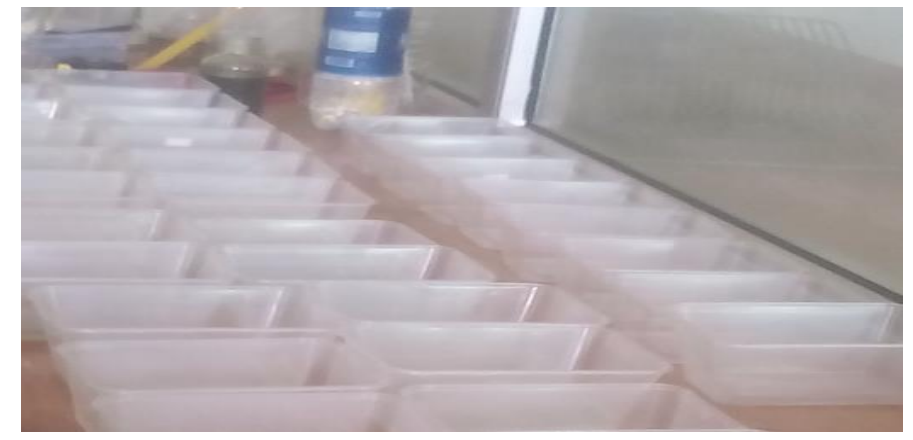

Figure 5. Picture of polyethylene jars arranged for range finding test 


\section{Analysis of data}

The percent mortality of nymphs in each replica of each concentration of each insecticide against each odonate species was calculated from cumulative total of 20 nymphs after 20 independent experiments (single nymph exposed to each concentration during each experiment). The average percent mortality data were subjected to log probit analysis (Finney, 1971) for calculating $\mathrm{LC}_{50}$ and $\mathrm{LC}_{90}$ values, using SPSS 16 software. The LC 50 values were compared by $95 \%$ confidence limits overlap method of Wheeler et al. (2006).

\section{Results}

\section{Sensitivity of damselfly and dragonfly nymphs to pyrethroids}

The sensitivity of odonate nymphs of damselfly (I. elegans) and dragonfly (T. aurora) were studied during exposure to three pyrethroids (deltamethrin, cypermethrin and lambdacyhalothrin) for 48 hours in laboratory conditions. Table 2 shows the 48-hour mortality data for three pyrethroids (deltamethrin, cypermethrin and lambdacyhalothrin) against the $7^{\text {th }}$ to $8^{\text {th }}$ instar nymphs of $I$. elegans. The highest concentrations of deltamethrin, cypermethrin and lambdacyhalothrin that caused no mortality of $I$. elegans were $0.0078 \mathrm{ppm}, 0.0039 \mathrm{ppm}$ and $0.00048 \mathrm{ppm}$, respectively. The lowest concentrations of deltamethrin, cypermethrin and lambdacyhalothrin that caused $100 \%$ mortality of I. elegans were $0.5 \mathrm{ppm}, 0.5 \mathrm{ppm}$ and $0.0156 \mathrm{ppm}$, respectively. Table 3 shows the 48-hour mortality data for three pyrethroids against the $7^{\text {th }}$ to $8^{\text {th }}$ nymphs of $T$. aurora. The highest concentrations of deltamethrin, cypermethrin and lambdacyhalothrin that caused no mortality of $T$. aurora were $0.0039 \mathrm{ppm}$, $0.00195 \mathrm{ppm}$ and $0.00048 \mathrm{ppm}$, respectively. The lowest concentrations of deltamethrin, cypermethrin and lambda cyhalothrin that caused $100 \%$ mortality of T. aurora were $0.25 \mathrm{ppm}, 0.25 \mathrm{ppm}$ and $0.0312 \mathrm{ppm}$, respectively.

Table 2. 48-hour percent mortality data for three pyrethroids against I. elegans nymph

\begin{tabular}{c|c|c}
\hline Pyrethroids & Concentrations & Mortality (Mean \pm SE) \% \\
\hline Deltamethrin & 0.0078 & 0 \\
& 0.0156 & $3.3 \pm 1.6$ \\
& 0.03125 & $6.6 \pm 1.6$ \\
& 0.0625 & $15 \pm 2.8$ \\
& 0.125 & $50 \pm 11.5$ \\
& 0.25 & $76.6 \pm 3.3$ \\
Cypermethrin & 0.5 & $100 \pm 0$ \\
\hline & 0.0039 & 0 \\
& 0.0078 & $3.3 \pm 1.6$ \\
& 0.0156 & $8.3 \pm 1.6$ \\
& 0.03125 & $16.6 \pm 3.3$ \\
& 0.0625 & $30 \pm 5.8$ \\
& 0.125 & $46.6 \pm 8.8$ \\
& 0.25 & $70 \pm 5.8$ \\
& 0.5 & $100 \pm 0$ \\
\hline Lambdacyhalothrin & 0.000485 & 0 \\
& 0.00097 & $10 \pm 2.8$ \\
& 0.00195 & $23.3 \pm 6$ \\
& 0.0039 & $51.6 \pm 4.4$ \\
& 0.0078 & $75 \pm 5.8$ \\
\hline
\end{tabular}


Table 3. 48-hour percent mortality data for three pyrethroids against T. aurora nymph

\begin{tabular}{c|c|c}
\hline Pyrethroids used & Concentration (ppm) & Mortality (Mean \pm SEM) \% \\
\hline Deltamethrin & 0.0039 & 0 \\
& 0.0078 & $3.3 \pm 1.6$ \\
& 0.0156 & $6.6 \pm 1.6$ \\
& 0.03125 & $18.3 \pm 6.01$ \\
& 0.0625 & $46.6 \pm 8.8$ \\
& 0.125 & $70 \pm 5.8$ \\
& 0.25 & $100 \pm 0$ \\
\hline Cypermethrin & 0.00195 & 0 \\
& 0.0039 & $1.6 \pm 1.6$ \\
& 0.0078 & $6.6 \pm 1.6$ \\
& 0.0156 & $15 \pm 2.8$ \\
& 0.03125 & $45 \pm 8.6$ \\
& 0.0625 & $66.6 \pm 8.8$ \\
& 0.125 & $86.6 \pm 3.3$ \\
& 0.25 & $100 \pm 0$ \\
\hline Lambdacyhalothrin & 0.000485 & 0 \\
& 0.00097 & $6.6 \pm 1.6$ \\
& 0.00195 & $15 \pm 2.8$ \\
& 0.0039 & $35 \pm 2.8$ \\
& 0.0078 & $61.6 \pm 4.4$ \\
& 0.0156 & $85 \pm 2.8$ \\
& 0.0312 & $100 \pm 0$ \\
\hline
\end{tabular}

\section{$L_{50}$ values of pyrethroids against damselfly and dragonfly nymphs}

Columns of the Table 4 show the comparison of $\mathrm{LC}_{50}$ values of three pyrethroids against nymph of each odonate species. During the study of $I$. elegans, significantly lower $\mathrm{LC}_{50}$ value (48-hour $\mathrm{LC}_{50}=0.004 \mathrm{ppm}$ ) was recorded for lambdacyhalothrin when compared with the $\mathrm{LC}_{50}$ values of deltamethrin and cypermethrin. Similarly, during the study of $T$. aurora, lowest $\mathrm{LC}_{50}$ value was recorded for lambdacyhalothrin $\left(\mathrm{LC}_{50}=0.005 \mathrm{ppm}\right)$ followed by cypermethrin $\left(\mathrm{LC}_{50}=0.038\right)$ and deltamethrin $(\mathrm{LC} 50=0.064)$. The $\mathrm{LC}_{50}$ values of all the three pyrethroids against $T$. aurora were significantly different from each other when compared through $95 \%$ confidence overlap method.

Table 4. 48-hour LC 50 values of three pyrethroids against I. elegans and T. aurora nymphs

\begin{tabular}{c|c|c}
\hline Pyrethroids & I. elegans & T. aurora \\
\hline Deltamethrin & $0.112(0.061-0.22) \mathrm{b}$ & $0.064(0.045-0.054) \mathrm{c}$ \\
Cypermethrin & $0.111(0.073-0.161) \mathrm{b}$ & $0.038(0.033-0.043) \mathrm{b}$ \\
Lambda cyhalothrin & $0.004(0.002-0.005) \mathrm{a}$ & $0.005(0.005-0.006) \mathrm{a}$ \\
\hline
\end{tabular}

The alphabetical order in column is according to increasing $\mathrm{LC}_{50}$ values. $\mathrm{LC}_{50}$ values sharing no letter are significantly different at $\mathrm{P}<0.05$ significance level

\section{Susceptibility of damselfly and dragonfly nymphs to organophosphates}

Table 5 shows the 48-hour mortality data for two organophosphates i.e., chlorpyrifos and dichlorvos against $7^{\text {th }}$ to $8^{\text {th }}$ instars nymphs of $I$. elegans. The highest concentrations of chlorpyrifos and dichlorvos that caused no mortality of I. elegans were $0.0078 \mathrm{ppm}$ and $0.0039 \mathrm{ppm}$, respectively. The lowest concentrations of chloropyrifos and 
dichlorovos that caused $100 \%$ mortality of I. elegans were $1.0 \mathrm{ppm}$ and $0.5 \mathrm{ppm}$, respectively. Table 6 shows the 48-hour mortality data for two organophosphates i.e., chlorpyrifos and dichlorvos against $7^{\text {th }}$ to $8^{\text {th }}$ instars nymphs of $T$. aurora. The highest concentrations of chloropyrifos and dichlorovos that caused no mortality of T. aurora were $0.0156 \mathrm{ppm}$ and $0.0078 \mathrm{ppm}$, respectively. The lowest concentrations of chloropyrifos and dichlorovos that caused $100 \%$ mortality of T. aurora were $2.0 \mathrm{ppm}$ and $1.0 \mathrm{ppm}$, respectively.

Table 5. 48-hour percent mortality data for two organophosphates against last instar nymph of I. elegans

\begin{tabular}{c|c|c}
\hline Organophosphates & Concentration $(\mathbf{p p m})$ & Mean \pm SE \% \\
\hline Chlorpyrifos & 0.0078 & 0 \\
& 0.0156 & $6.6 \pm 1.6$ \\
& 0.03125 & $8.3 \pm 1.6$ \\
& 0.0625 & $23.3 \pm 6.1$ \\
& 0.125 & $46.6 \pm 8.8$ \\
& 0.25 & $61.6 \pm 10.1$ \\
& 0.5 & $83.3 \pm 6.6$ \\
& 1 & $100 \pm 0$ \\
\hline \multirow{2}{*}{ Dichlorvos } & 0.0039 & 0 \\
& 0.0078 & $3.3 \pm 1.6$ \\
& 0.0156 & $6.6 \pm 1.6$ \\
& 0.03125 & $10 \pm 2.8$ \\
& 0.0625 & $18.3 \pm 6.01$ \\
& 0.125 & $45 \pm 5.8$ \\
& 0.25 & $66.6 \pm 8.8$ \\
& 0.5 & $100 \pm 0$ \\
\hline
\end{tabular}

Table 6. 48-hour mortality data for two organophosphates against last instar nymphs of T. aurora

\begin{tabular}{c|c|c}
\hline Organophosphates & Concentration $(\mathbf{p p m})$ & Mean \pm SEM \% \\
\hline Chlorpyrifos & 0.0156 & 0 \\
& 0.03125 & $3.3 \pm 1.6$ \\
& 0.0625 & $15 \pm 2.8$ \\
& 0.125 & $35 \pm 8.6$ \\
& 0.25 & $46.6 \pm 12.01$ \\
& 0.5 & $63.3 \pm 12.01$ \\
& 1 & $81.6 \pm 4.4$ \\
& 2 & $100 \pm 0$ \\
\hline Dichlorvos & 0.0078 & 0 \\
& 0.0156 & $1.6 \pm 1.6$ \\
& 0.03125 & $8.3 \pm 1.6$ \\
& 0.0625 & $23.3 \pm 8.8$ \\
& 0.125 & $53.3 \pm 14.5$ \\
& 0.25 & $80 \pm 5.8$ \\
& 0.5 & $93.3 \pm 3.3$ \\
& 1 & $100 \pm 0$ \\
\hline
\end{tabular}

\section{$L_{50}$ values of organophosphates against damselfly and dragonfly nymphs}

Figure 6 shows the $\mathrm{LC}_{50}$ values of chloropyrifos and dichlorovos against I. elegans. The $\mathrm{LC}_{50}$ values of chloropyrifos and dichlorovos against I. elegans were $0.142 \mathrm{ppm}$ 
and $0.125 \mathrm{ppm}$, respectively. Based on $95 \%$ confidence interval overlap method, there was no significant difference in the $\mathrm{LC}_{50}$ values of dichlorovos and chloropyrifos against I. elegans. Figure 7 shows the $\mathrm{LC}_{50}$ values of chlorpyrifos and dichlorovos against $T$. aurora. The $\mathrm{LC}_{50}$ values of chloropyrifos and dichlorovos against $T$. aurora were $0.257 \mathrm{ppm}$ and $0.119 \mathrm{ppm}$, respectively. Based on $95 \%$ confidence interval overlap method, the $\mathrm{LC}_{50}$ value of dichlorovos against $T$. aurora was significantly lower when compared to the $\mathrm{LC}_{50}$ value chloropyrifos against $T$. aurora.

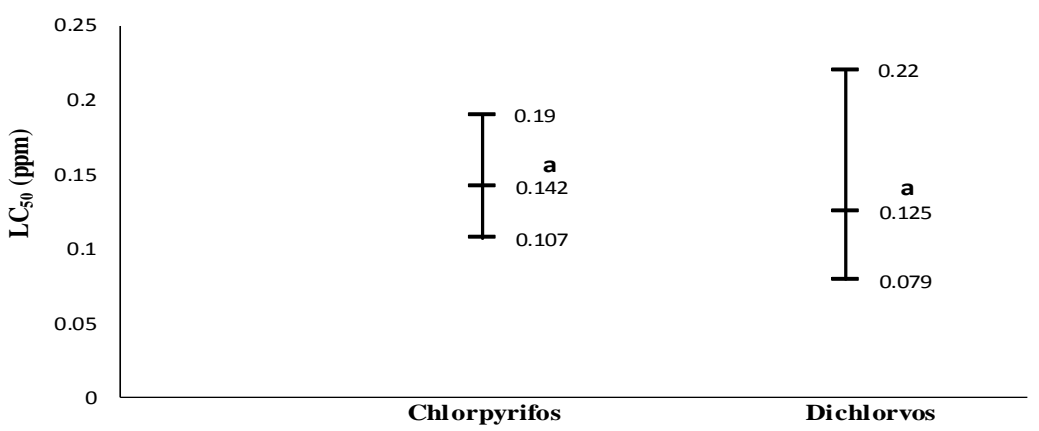

Figure 6. Comparison of $L C_{50}$ values of chlorpyrifos and dichlorvos against I. elegans. Error bars represent $95 \%$ confidence limits. Similar letter represents that LC50 values are not different significantly at $P<0.05$ significance level

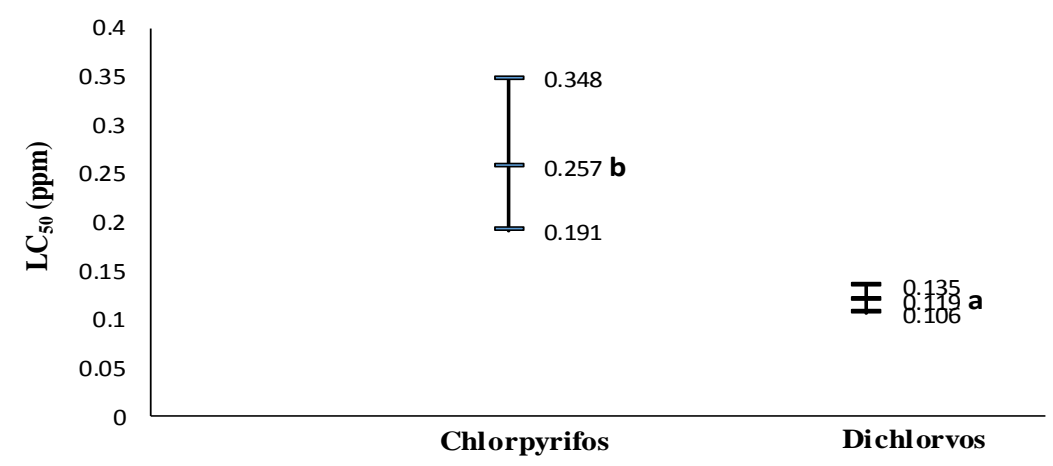

Figure 7. Comparison of $L C_{50}$ values of chlorpyrifos and dichlorvos against T. aurora. Error bars represent $95 \%$ confidence limits. Different letters represent that LC50 values are significantly different at $P<0.05$ significance level

Figure 8 shows the comparisons of chlorpyrifos $\mathrm{LC}_{50}$ values for I. elegans and T. aurora. The $\mathrm{LC}_{50}$ value of chloropyrifos for I. elegans $(0.142 \mathrm{ppm})$ was significantly lower than its $\mathrm{LC}_{50}$ value for $T$. aurora $(0.3 \mathrm{ppm})$. Figure 9 shows the comparison of dichlorvos $\mathrm{LC}_{50}$ values for I. elegans $(0.125 \mathrm{ppm})$ and $T$. aurora $(0.12 \mathrm{ppm})$. There was no significant difference in the $\mathrm{LC}_{50}$ values of dichlorvos for I. elegans and T. aurora.

\section{Sensitivity of damselfly and dragonfly nymphs to neonicotinoid}

Table 7 shows the 48 -hour mortality data of acetamiprid against the nymphs $\left(7^{\text {th }}\right.$ to $8^{\text {th }}$ instar) of $I$. elegans and T. aurora. The highest concentrations of acetamiprid that caused no mortality of $I$. elegans was $0.00195 \mathrm{ppm}$. The highest concentration of acetamiprid that caused no mortality of T. aurora was $0.000975 \mathrm{ppm}$. The lowest 
concentrations of acetamiprid that caused $100 \%$ mortality of $I$. elegans and T. aurora were $0.25 \mathrm{ppm}$ and $0.125 \mathrm{ppm}$, respectively.

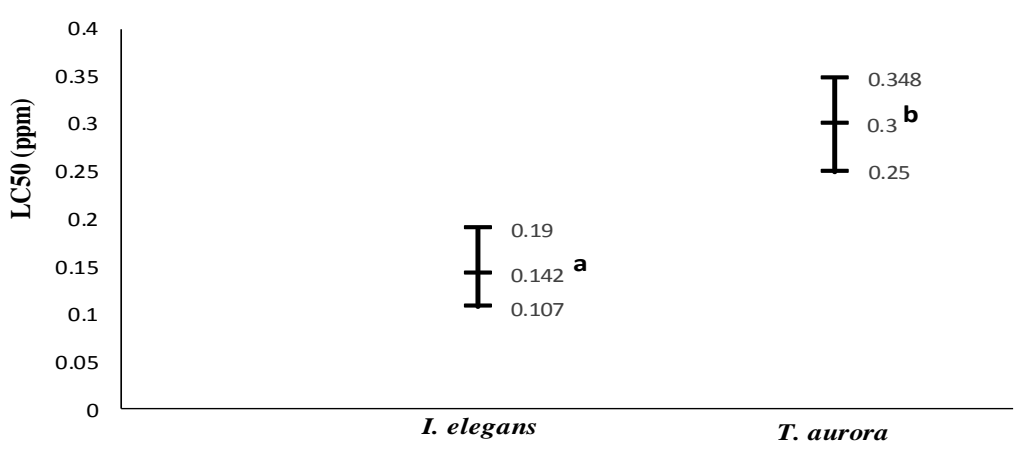

Figure 8. Comparison of chlorpyrifos $L C_{50}$ values for I. elegans and T. aurora. Error bars represent $95 \%$ confidence limits. Different letters represent that $L C_{50}$ values are significantly different at $P<0.05$ significance level

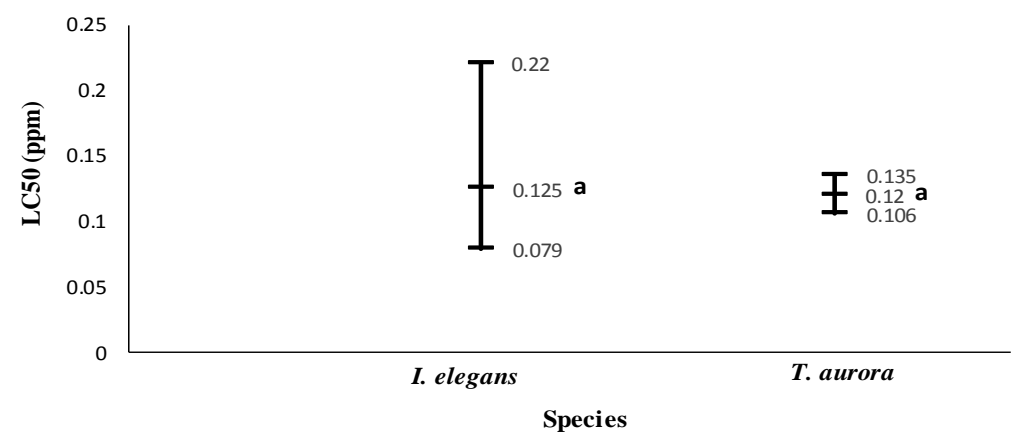

Figure 9. Comparison of dichlorvos $L C_{50}$ values for I. elegans and T. aurora. Error bars represent $95 \%$ confidence limits. Similar letter represents that $L C_{50}$ values ate not different significantly at $P<0.05$ significance level

Table 7. 48-hour percent mortality data for a neonicotinoid, acetamiprid against damselfly and dragonfly nymphs nymphs

\begin{tabular}{c|c|c}
\hline Odonate species & Concentration $(\mathbf{p p m})$ & Mean \pm SEM \% \\
\hline I. elegans & 0.00195 & 0 \\
& 0.0039 & $3.3 \pm 1.6$ \\
& 0.0078 & $10 \pm 2.8$ \\
& 0.0156 & $18.3 \pm 4.4$ \\
& 0.03125 & $46.6 \pm 8.8$ \\
& 0.0625 & $56.6 \pm 8.8$ \\
& 0.125 & $85 \pm 2.8$ \\
& 0.25 & $100 \pm 0$ \\
\hline T. aurora & 0.000975 & 0 \\
& 0.00195 & $3.3 \pm 1.6$ \\
& 0.0039 & $6.6 \pm 1.6$ \\
& 0.0078 & $16.6 \pm 7.3$ \\
& 0.0156 & $30 \pm 11.5$ \\
& 0.03125 & $56.6 \pm 8.8$ \\
& 0.0625 & $80 \pm 5.8$ \\
& 0.125 & $100 \pm 0$ \\
\hline
\end{tabular}




\section{$L_{50}$ values of neonicotinoid against damselfly and dragonfly nymphs}

Figure 10 shows the $\mathrm{LC}_{50}$ values of a neonicotinoid, acetamiprid against predator of mosquito larvae i.e., I. elegans and T. aurora. The $\mathrm{LC}_{50}$ values of acetamiprid against I. elegans and T. aurora were $0.038 \mathrm{ppm}$ and $0.023 \mathrm{ppm}$, respectively. Based on $95 \%$ confidence interval overlap method, the $\mathrm{LC}_{50}$ value of acetamiprid for $T$. aurora was significantly lower than its $\mathrm{LC}_{50}$ value for I. elegans.

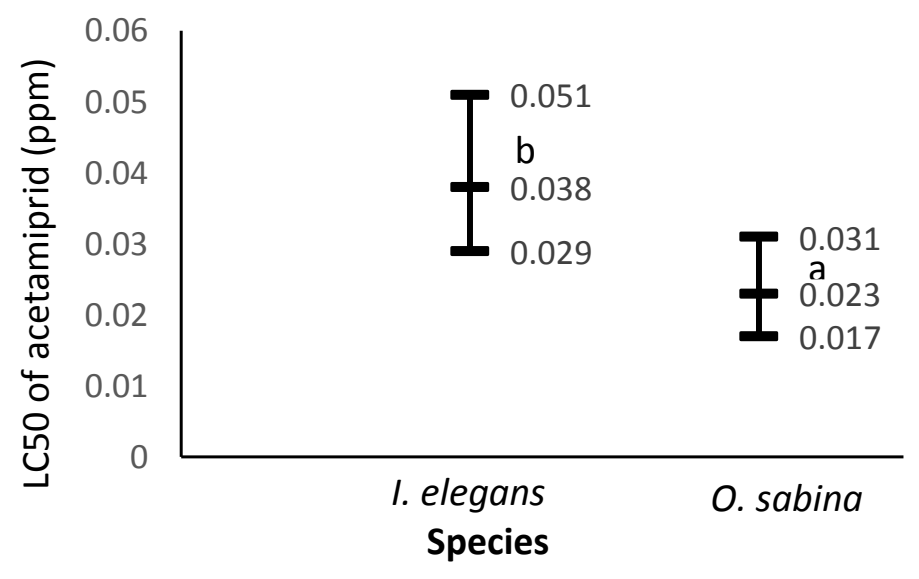

Figure 10. $L C_{50}$ values of acetamiprid against I. elegans and T. aurora. Error bars represent 95 $\%$ confidence limits. Different letters represent that $L C_{50}$ values are significantly different at $P<0.05$ significance level

\section{LC90 values of six insecticides against damselfly and dragonfly nymphs}

Table 8 shows the $\mathrm{LC}_{90}$ values of six insecticides for $I$. elegans. Minimum $\mathrm{LC}_{90}$ values was observed for lambda cyhalothrin $(0.01 \mathrm{ppm})$. The $\mathrm{LC}_{90}$ value of lambda cyhalothrin was significantly different from the $\mathrm{LC}_{90}$ values of the remaining insecticides. Next to the lambda cyhalothrin, acetamiprid showed lowest $\mathrm{LC}_{90}$ value $(0.122 \mathrm{ppm})$ which was significantly different from the $\mathrm{LC}_{90}$ values of the remaining insecticides. Maximum LC 90 value was observed for chlorpyrifos $(0.655 \mathrm{ppm})$ and dichlorvos $(0.535 \mathrm{ppm})$. The difference in LC90 values against I. elegans among chlorpyrifos, dichlorvos, cypermethrin and deltamethrin were not significant.

Table 8. 48-hour $L C_{90}$ values of six insecticides against I. elegans nymph

\begin{tabular}{c|c}
\hline Insecticides & LC90 (95 \% confidence limits) \\
\hline Deltamethrin & $0.351(0.188-2.19) \mathrm{c}$ \\
Cypermethrin & $0.504(0.291-1.35) \mathrm{c}$ \\
Lambda cyhalothrin & $0.01(0.007-0.027) \mathrm{a}$ \\
Chlorpyrifos & $0.655(0.436-1.214) \mathrm{c}$ \\
Dichlorvos & $0.535(0.283-2.108) \mathrm{c}$ \\
Acetamiprid & $0.122(0.086-0.204) \mathrm{b}$ \\
\hline
\end{tabular}

The alphabetical order in columns is according to increasing $\mathrm{LC}_{90}$ values. $\mathrm{LC} \mathrm{9}_{0}$ values sharing no letter are significantly different 
Table 9 shows the $\mathrm{LC}_{90}$ values of six insecticides for $T$. aurora. Minimum $\mathrm{LC}_{90}$ value was observed for lambdacyhalothrin $(0.018 \mathrm{n} p \mathrm{pm})$. The $\mathrm{LC}_{90}$ value of Lambdacyhalothrin was significantly different from the $\mathrm{LC}_{90}$ values of the remaining insecticides. The second most toxic insecticide was acetamiprid which showed $\mathrm{LC}_{90}$ value of $0.093 \mathrm{ppm}$. Maximum LC 90 value was observed for chlorpyrifos (1.306 ppm). The second least toxic insecticide was dichlorvos with LC90 value of $0.404 \mathrm{ppm}$. The $\mathrm{LC}_{90}$ value of chloropyrifos was significantly different from the $\mathrm{LC}_{90}$ values of other insecticides. The $\mathrm{LC}_{90}$ value of dichlorvos was insignificantly higher than the $\mathrm{LC}_{90}$ value of deltamethrin however it was significantly higher than the $\mathrm{LC}_{90}$ value of cypermethrin.

Table 9. 48-hour LC 90 values of six insecticides against of T. aurora nymph

\begin{tabular}{c|c}
\hline Insecticides & LC90 (95\% confidence limits) \\
\hline Deltamethrin & $0.205(0.13-0.49) \mathrm{d}$ \\
Cypermethrin & $0.132(0.11-0.165) \mathrm{c}$ \\
Lambda cyhalothrin & $0.018(0.015-0.023) \mathrm{a}$ \\
Chlorpyrifos & $1.306(0.852-2.526) \mathrm{e}$ \\
Dichlorvos & $0.404(0.34-0.498) \mathrm{d}$ \\
Acetamiprid & $0.093(0.062-0.174) \mathrm{b}$ \\
\hline
\end{tabular}

The alphabetical order in columns is according to increasing $\mathrm{LC}_{90}$ values. $\mathrm{LC} 9_{0}$ values sharing no letter are significantly different

\section{Discussion}

During the study of susceptibility of predators of mosquito larvae (I. elegans and T. aurora) to pyrethroids, the predators were found more susceptible to lambdacyhalothrin than to deltamethrin and cypermethrin (Tables 2-3). The 48-hour $\mathrm{LC}_{50}$ values of lambdacyhalothrin against nymphs of I. elegans and T. aurora were significantly lower when compared to the 48-hour $\mathrm{LC}_{50}$ values of deltamethrin and cypermethrin against these nymphs (Table 4). Aquatic insects appear highly susceptible to synthetic pyrethroids, even very low concentration $(<1 \mu \mathrm{g} / \mathrm{L})$ of pyrethroid can create toxic effects (Mian and Mulla, 1992). The high sensitivity of aquatic insects to synthetic pyrethroid may be attributed to disruption of ionic balance in aquatic insects (Coats et al., 1989). During the present study, I. elegans showed similar sensitivity to both, deltamethrin and cypermethrin ( $\mathrm{LC}_{50}$ of deltamethrin $=0.112 \mathrm{ppm}, \mathrm{LC}_{50}$ of cypermethrin $=0.111 \mathrm{ppm})($ Table 4$)$. Such trend has been also observed in the reported work of Beketov (2004), where Daphnia magna showed similar susceptibility to two different synthetic pyrethroids, deltamethrin and esfenvalerate. Their 96-hour LC $_{50}$ values of deltamethrin and esfenvalerate were $0.00003 \mathrm{ppm}$ and $0.00003 \mathrm{ppm}$, respectively. During the present study, T. aurora appeared more susceptible to cypermethrin $\left(\mathrm{LC}_{50}=0.038 \mathrm{ppm}\right)$ than deltamethrin $\left(\mathrm{LC}_{50}=0.064 \mathrm{ppm}\right)($ Table 4$)$. It has been reported that a given insect species may not be equally susceptible to different insecticides of the same class (Boiteau and Noronha, 2007; Nielsen et al., 2008).

During the present study, the susceptibility of nymphs of I. elegans and T. aurora to a particular pyrethroids was not the same. During lambdacyhalothrin toxicity study, nymphs of I. elegans were more susceptible than nymphs of T. aurora. On the other hand, during deltamethrin and cypermethrin toxicity study, nymphs of $T$. aurora were found more susceptible than nymphs of I. elegans (Table 4). It has been shown that different insect species may respond differently to an insecticide (Banks et al., 2017). 
The differential tolerance of different insect species to an insecticide is due to differences in size, behavior, insecticide penetration, target sensitivity, excretion and metabolism (Wen et al., 2011). The enzymes P450 catalyse the oxidation of toxic compounds in the presence of NADPH cytochrome P450-reductase and or cytochrome b5 which are obligatory electron donor (Murataliev et al., 2008). The resistance of insects to insecticides is due to the presence of P450 enzymes (Karunker et al., 2009). Deltamethrin, cypermethrin and lambda-cyhalothrin that were studied for their toxicity with odonate nymphs during the present research, belong to type II pyrethroids. These pyrethroids cause hyperactivity, incoordination, convulsions and writhing. These type II pyrethroids produce stimulus-dependent nerve depolarization and blockage (Ecobichon, 1996).

The toxicity of deltamethrin with aquatic invertebrates has been reported. For example, Beketov (2002), studied the comparative sensitivity of larvae of damselfly, dragonfly, mayfly and Daphnia magna to deltamethrin and esfenvalerate. They reported the deltamethrin 48-hour $\mathrm{LC}_{50}$ values of $0.0000145 \mathrm{ppm}$ and $0.000076 \mathrm{ppm}$ against nymphs of one damselfly species, Lestes sponsa and one dragonfly species such as Cordulia aenea, respectively. During the present research, the $\mathrm{LC}_{50}$ values of deltamethrin against odonate nymphs were well above than the $\mathrm{LC}_{50}$ values of deltamethrin reported by Beketov (2002). This difference might be explained by differences in species, brand of insecticides and experimental design. Deltamethrin toxicity with other invertebrates has also been reported. For example, de Castro et al. (2013) exposed the major lepidopteran pest of soybean, Anticarsia gemmatalis and its predators Podisus nigrispinus and Supputius cincticeps (Heteroptera: Pentatomidae) to deltamethrin, methamidophos, spinosad and chlorantraniliprole. The $\mathrm{LC}_{50}$ values of deltamethrin against Anticarsia gemmatalis, Podisus nigrispinus and Supputius cincticeps were $2.76 \mathrm{ppm}, 1.83 \mathrm{ppm}$ and $1.83 \mathrm{ppm}$, respectively.

Lambdacyhalothrin toxicity to aquatic invertebrates has been reported. For example, in laboratory tests, the 48-hour $\mathrm{EC}_{50}$ value of lambdacyhalothrin against nymph of I. elegans was 0.00013 ppm (Maund et al., 1998). Schroer et al. (2004) studied the toxicity of the pyrethroid insecticide $\chi$-cyhalothrin to freshwater invertebrates in laboratory, in situ bioassays and in field microcosms. In laboratory tests, the 48-hour LC $_{50}$ value against Erythromma viridulum (Zygoptera, dragonflies) was 0.001583 ppm, Asellus aquaticus (Crustacea, Isopoda) 0.00014 ppm, Gammarus pulex (Crustacea, Amphipoda) 0.0000314 ppm, Cloeon dipterum (Ephemeroptera, mayflies) $0.000122 \mathrm{ppm}$, Sigara striata (Hemiptera, true bugs) $0.0000492 \mathrm{ppm}$ and Daphnia galeata (Crustacea, Cladocera) was $0.397 \mathrm{ppm}$. The 48-hour LC $_{50}$ values of lambdacyhalothrin against I. elegans and T. aurora observed during the present research are far below than the lambdacyhalothrin 48-hour LC $_{50}$ values reported by Maund et al. (1998) and Schroer et al. (2004).

Organophosphate insecticides cause toxicity through inhibition of acetylcholinesterase, which is responsible for the degradation of the excitatory neurotransmitter, acetylcholine, thereby terminating transmission of nerve impulses at cholinergic synapses (Fukuto, 1990). Inhibition of this enzyme prolongs the residence time of acetylcholine at synapses resulting in hyper-excitation and eventual death (Fukuto, 1990). During the present study, I. elegans was found more susceptible to dichlorovos than to chlorpyrifos (Table 5). The lowest concentration of dichlorvos that caused $100 \%$ mortality of I. elegans nymphs was lower than the lowest concentration of chlorpyrifos that caused $100 \%$ mortality of I. elegans nymphs. The 48-hour LC50 value 
of dichlorvos for I. elegans nymphs was significantly lower than the 48-hour LC value of chlorpyrifos for I. elegans nymphs (Figure 6). Similar trend was observed during the study of susceptibility of T. aurora to chloropyrifos and dichlorvos (Table 6, Figure 7). The findings of the present research showed that nymphs of I. elegans and T. aurora are more susceptible to dichlorvos than to chlorpyrifos. Similar trend was also reported by Ahmed and Irfanullah (2004). They studied the toxicity of dichlorvos and chlorpyrifos against house fly, Musca domestica. They reported dichlorvos as the most effective insecticide. Gupta et al. (2007) reported dichlorvos more deleterious than chlorpyrifos against fly. Chloropyrifos toxicity with aquatic stages of invertebrates has been reported. For example, Rubach et al. (2010) reported the toxicokinetic variation in 15 freshwater arthropod species exposed to the insecticide chlorpyrifos. The 48-hour LC 50 values of larvae of Anax imperator (Anisoptera, dragonflies), Chaoborus obscuripes (Diptera), Cloeon dipterum (Ephemeroptera, mayflies) and Sialis lutaria (Megaloptera) were $0.00313 \mathrm{ppm}, 0.000438 \mathrm{ppm}, 0.000763 \mathrm{ppm}$ and $0.00155 \mathrm{ppm}$, respectively. During the present research, the 48-hour $\mathrm{LC}_{50}$ value of chloropyrifos for I. elegans and T. aurora were $0.142 \mathrm{ppm}$ and $0.3 \mathrm{ppm}$, respectively (Figure 8). These $\mathrm{LC}_{50}$ values are far above than the $\mathrm{LC}_{50}$ values reported by and Rubach et al. (2010) for chlorpyrifos against aquatic stages of Odonates or other insect species. To the author knowledge there are no reports about the toxicity of dichlorovos with the nymphs of I. elegans and T. aurora. However, there are reports about dichlorovos toxicity with fish (Kumar and Gautam, 2014; Patar et al., 2015), birds (Ezeji and Onwurah, 2017), mammals (WHO, 1989) and other aquatic organisms (McHenery et al., 1996). US EPA Ecotox database was searched for the $\mathrm{LC}_{50}$ values of dichlorvos against damselfly and dragonfly nymphs. In the database, 24-hour $\mathrm{LC}_{50}$ values of dichlorvos against the damselfly nymphs of Agriocnemis sp., Copera sp. and Ceriagrion sp. were $4.57 \mathrm{ppm}, 0.91 \mathrm{ppm}$ and $0.63 \mathrm{ppm}$, respectively. The experimental medium was fresh water and the experiments were conducted in laboratory. The 24-hour $\mathrm{LC}_{50}$ value of dichlorvos for the nymphs of Agriocnemis sp. is far above than the 48-hour dichlorvos $\mathrm{LC}_{50}$ values for the I. elegans and T. aurora nymphs during the present research. The 24-hour $\mathrm{LC}_{50}$ value of dichlorvos for the nymphs of Copera sp. and Ceriagrion sp. were closer to the 48-hour $\mathrm{LC}_{50}$ value of dichlorovos against $I$. elegans and $T$. aurora during the present study.

The nymphs of $I$. elegans and T. aurora, showed different susceptibility against chlorpyrifos. For example, during exposure to chlorpyrifos, I. elegans was found more susceptible than $T$. aurora (Figure 8). All insecticides are not equally toxic to a given insect species, neither is a given insecticide equally effective against all insect species (Boiteau and Noronha, 2007; Nielsen et al., 2008). It has been shown that different insect species may respond differently to different insecticides (Banks et al., 2017). Differences among insect species in their capacity for P450-mediated detoxification of insecticides are an important factor responsible for differential tolerance among insect species to insecticides (Wen et al., 2011). During the present research, the susceptibility of I. elegans and T. aurora to acetamiprid (a neonicotinoid) were studied (Table 7). The nymphs of $T$. aurora was more susceptible than I. elegans nymphs. The 48-hour LC 50 value of acetamiprid for $T$. aurora $\left(\mathrm{LC}_{50}=0.023 \mathrm{ppm}\right)$ was significantly lower than its $\mathrm{LC}_{50}$ value for I. elegans $\left(\mathrm{LC}_{50}=0.038 \mathrm{ppm}\right)$ (Figure 10). Thus $T$. aurora was found more sensitive to acetamiprid than I. elegans. It has been already reported that different insect species respond differently to an insecticide (Banks et al., 2017). Neonicotinoids act as agonists on nicotinic acetylcholine receptors (nAChRs) opening cation channels (Casida and Durkin, 2013). At the same time, voltage-gated calcium channels are also 
involved (Jepson et al., 2006). This agonistic action results in continuous excitation of neuronal membrane, production of discharge that lead to paralysis and exhaustion of cell energy that leads to the death of insects. Thus, the channel opening of nAChRs induced by the binding of neonicotinoids to receptors leads to insecticidal activity (Nishiwaki et al., 2003). To the author knowledge, there are no reports about the $\mathrm{LC}_{50}$ values of acetamiprid with dragonflies or damselflies nymphs. However, acetamiprid toxicity with other terrestrial and aquatic invertebrates has been reported. For example, the acetamiprid 48 hours LC $_{50}$ value of 49.8 ppm against Daphnia magna in static fresh water condition has been reported (Mineau and Palmer, 2013). Wang et al. (2012) studied the comparative acute toxicity of 24 insecticides against earthworm, Eisenia fetida. The $\mathrm{LC}_{50}$ values of $0.0088 \mu \mathrm{g} / \mathrm{cm}^{2}$ and $1.52 \mathrm{mg} / \mathrm{kg}$ were observed for acetamiprid against Eisenia fetida during contact filter paper test and contact artificial soil test, respectively.

During the present study, the $\mathrm{LC}_{90}$ values of different insecticides for the nymphs of I. elegans and T. aurora were compared (Tables 8-9). Based on the comparison of LC 90 values, I. elegans and T. aurora were found more susceptible to lambdacyhalothrin and acetamiprid. They were found least susceptible to chloropyrifos and dichlorovos. These results are in accordance with the early reports about the toxicity of different classes of insecticides to the aquatic insects and other invertebrates. According to Poirier and Surgeoner (1988), organophosphates insecticides and carbamates insecticides are less toxic to insect larvae but very toxic to some species. According to Anderson (1989), the most toxic group of insecticides is the pyrethroids which have broad spectrum of activity and kill most species.

\section{Conclusion and recommendation}

From the findings of the present study, it was concluded that damselfly i.e., Ischnura elegans and dragonfly i.e., Trithemis aurora nymphs are highly sensitive to a pyrethroid, lambda cyhalothrin and a neonicotinoid, acetamiprid. Synthetic chemical insecticides are highly toxic to damselfly and dragonfly nymphs even at very low concentrations. The application of synthetic chemical insecticides should be minimized and safe application in the areas adjacent to aquatic habitats must be ensured. Application of other methods of insect pest control such as integrated pest management should be encouraged. Further research is recommended for determining the effect of environmentally realistic high concentrations of agricultural insecticides in water bodies of agricultural areas on the predator avoidance behavior, development and predatory ability of odonate nymphs.

\section{REFERENCES}

[1] Ahmed, S., Irfanullah, M. (2004): Toxicity of dichlorvos 50ec and chlorpyrifos 40ec against house fly, Musca domestica L. - Pak J Agri Sci 41(1): 65-71.

[2] Anderson, R. L. (1989): Toxicity of synthetic pyrethroids to fresh water invertebrates. Environ Toxicol Chem 8(5): 4003-4010.

[3] Anderson, J. C., Dubetz, C., Palace, V. P. (2015): Neonicotinoids in the Canadian aquatic environment: a literature review on current use products with a focus on fate, exposure, and biological effects. - Sci Total Environ 505: 409-22. 
[4] Anjum, S. A. (1997): Biosystematics of odonate naiads of the Punjab by rearing techniques. - M.Sc. thesis, Department of Agriculture Entomology University of Agriculture Faisalabad, Pakistan.

[5] Armbrust, K. L., Peeler, H. B. (2002): Effects of formulation on the run-off of imidacloprid from turf. - Pest Manag Sci 58(7): 702-706.

[6] ASTM- American Society for Testing and Materials (2008): Guide for Conducting Acute Toxicity Tests on Aqueous Ambient Samples and Effluents with Fishes, Macroinvertebrates, and Amphibians. - ASTM International.

[7] Banks, J. E., Vargas, R. I., Ackleh, A. S., Stark, J. D. (2017): Sublethal Effects in Pest Management: A SurrogateSpecies Perspective on Fruit Fly Control. - Insects 8: 78.

[8] Beketov, M. A. (2002): Ammonia toxicity to larvae of Erythromma najas (Hansemann), Lestes sponsa (Hansemann) and Sympetrum flaveolum (Linnaeus) (Zygoptera: Coenagrionidae, Lestidae; Anisoptera: Libellulidae). - Odonatologica 31(3): 297-304.

[9] Boiteau, G., Noronha, C. (2007): Topical, residual and ovicidal contact toxicity of three reduced-risk insecticides against the European corn borer, Ostrinia nubilalis (Lepidoptera: Crambidae), on potato. - Pest Manag Sci 63: 1230-1238.

[10] Boyd, S. (2005): Damselflies and dragonflies. Scientific Illustration Major. - University of Georgia, Athens. http://www.discoverlife.org/nh/tx/Insecta/Odonata/.

[11] Cai, Z., Wang, D., Ma, W. T. (2004): Gas chromatography/ion trap mass spectrometry applied for the analysis of triazine herbicides in environmental waters by an isotope dilution technique. - Analytica Chimica Acta 503: 263-270.

[12] Casida, J. E., Durkin, K. A. (2013): Neuroactive insecticides: targets, selectivity, resistance, and secondary effects. - Annu Rev Entomol 58: 99-117.

[13] Coats, J. R., Symonik, D. M., Bradbury, S. P., Dyer, S. D., Timson, L. K., Atchison, G. J. (1989): Toxicology of synthetic pyrethroids in aquaticorganisms: An overview. - Environ Toxicol Chem 8: 671-679.

[14] Davies, J. H. (1985): The pyrethroids: an historical introduction. - In: Leahey, J. P. (ed.) The Pyrethroid Insecticides. Taylor and Francis, Philadelphia, pp. 1-40.

[15] de Castro, A. A., Corrêa, A. S., Legaspi, J. I., Guedes, R. N. C., Serrão, J. E., Zanuncio, J. C. (2013): Survival and behavior of the insecticide-exposed predators Podisus nigrispinus and Supputius cincticeps (Heteroptera: Pentatomidae). - Chemosphere 93(6): 1043-1050.

[16] Din, A. U., Zia, A., Bhatti, A. R., Khan, M. N. (2013): Odonata naiads of Potohar Plateau, Punjab, Pakistan. - Pakistan J Zool 45: 695-700.

[17] Ecobichon, D. J. (1996): Toxic effects of pesticides. - In: Klaassen, C. D., Amdur, M. O., Doull, J. (eds.) Casarett \& Doull's Toxicology: The BasicScience of Poisons. McGrawHill, Health Professions Division. New York, NY. pp. 643-690.

[18] Ezeji, E. U., Onwurah, I. N. E. (2017): Biochemical Effects of Dichlorvos Pesticide on the Liver of Poultry Birds (Gallus domestica). - American Journal of Biochemistry 7(2): 23-26.

[19] Fenoll, J., Vela, N., Garrido, I., Pérez-Lucas, G., Navarro, S. (2014): Abatement of spinosad and indoxacarb residues in pure water by photocatalytic treatment using binary and ternary oxides of Zn and Ti. - Environ Sci Pollut Res 21(21): 12143-12153.

[20] Finney, D. J. (1971): Probit analysis. - Cambridge University Press, London, pp. 68-78.

[21] Fukuto, T. R. (1990): Mechanism of Action of Organophosphorus and Carbamate Insecticides. - Environmental Health Perspectives 87: 245-254.

[22] Gullan, P. J., Cranston, P. S. (2005): The Insects: An Outline of Entomology, $3^{\text {rd }}$ Edition. - Blackwell Publishing Ltd.

[23] Gupta, S. C., Siddique, H. R., Mathur, N., Vishwakarma, A. L., Mishra, R. K., Saxena, D. K., Chowdhuri, D. K. (2007): Induction of hsp70, alterations in oxidative stress markers and apoptosis against dichlorvos exposure in transgenic Drosophila melanogaster: modulation by reactive oxygen species. - Biochim Biophys Acta 1770(9): 1382-1394.

[24] Hilz, B. E., Vermeer, A. W. P. (2012): Effects of formulation on spray drift: a case study for commercial imidacloprid products. - Asp Appl Biol 114: 445-450. 
[25] Huynh, H., Nugegoda, D. (2012): Effects of chlorpyrifos on growth and food utilization in Australian catfish, Tandanus tandanus. - Bull Environ Contam Toxicol 88: 25-29.

[26] Jayaraj, R., Megha, P., Sreedev, P. (2016): Organochlorine pesticides, their toxic effects on living organisms and their fate in the environment. - Interdiscip Toxicol 9(3-4): 90-100.

[27] Jepson, J. E. C., Brown, L. A., Sattelle, D. B. (2006): The actions of the neonicotinoid imidacloprid on cholinergic neurons of Drosophila melanogaster. - Invert Neurosci 6: 33-40.

[28] Karunker, I., Morou, E., Nikou, D., Nauen, R., Sertchook, R., Stevenson, B. J., Paine, M. J., Morin, S., Vontas, J. (2009): Structural model and functional characterization of the Bemisia tabaci CYP6CM1vQ, a cytochrome P450 associated with high levels of imidacloprid resistance. - Insect Biochem Mol Biol 39: 697-706.

[29] Kumar, S., Gautam, R. K. (2014): Study of biochemical toxicity of nuvan in Channa punctatus (Bloch.). - Adv Res Agri Veter Sci 1(1): 31-34.

[30] Lourencetti, C., Marchi, M. R. R., Ribeiro, M. L. (2008): Determination of sugar cane herbicides in soil and soil treated with sugar cane vinasse by solid-phase extraction and HPLC UV. - Talanta 77: 701-709.

[31] Malev, O., Klobucar, R. S., Fabbretti, E., Trebse, P. (2012): Comparative toxicity of imidacloprid and its transformation product 6-chloronicotinic acid to non-target aquatic organisms: microalgae Desmodesmus subspicatus and amphipod Gammarus fossarum. Pestic Biochem Phys 104(3): 178-86.

[32] Maund, S. J., Hamer, M. J., Warinton, J. S., Kedwards, T. J. (1998): Aquatic ecotoxicology of the pyrethroid insecticide lambda-cyhalothrin: Considerations for higher-tier aquatic risk assessment. - Pestic Sci 54: 408-417.

[33] McHenery, J. G., Francis, C., Davies, I. M. (1996): Threshold toxicity and repeated exposure studies of dichlorvos to the larvae of thecommon lobster (Homarus gammarus L.). - Aquat Toxicol 34(3): 237-251.

[34] Mian, L., Mulla, M. (1992): Effects of pyrethroid insecticides on non-targetinvertebrates in aquatic ecosystems. - J Agric Entomol 9: 73-98.

[35] Mineau, P., Palmer, C. (2013): Neonicotinoid insecticides and birds: the impact of thenation's most widely used insecticides on birds. - American Bird Conservancy.

[36] Mitra, T. R. (2002): Geographical distribution of Odonate (Insecta) of Eastern India (Memoirs Zool Survey India). - Zoological Survey of India, 203p.

[37] Mitra, A. (2006): Current status of the Odonata of Bhutan: A checklist with four new records. - Bhu JRNR 2(1): 136-143.

[38] Mokry, L. E., Hoagland, K. D. (1990): Acutetoxicities of five synthetic pyrethroid insecticidesto Daphnia magna and Ceriodaphnia dubia. - Environ Toxicol Chem 9: 1045-1051.

[39] Morrissey, C. A., Mineau, P., Devries, J. H., Sanchez-Bayo, F., Liess, M., Cavallaro, M. C., Liber, K. (2015): Neonicotinoid contamination of global surface waters and associated risk to aquatic invertebrates: a review. - Environ Int 74: 291-303.

[40] Murataliev, M. B., Guzov, V. M., Walker, F. A., Feyereisen, R. (2008): P450 reeducates and cytochrome b5 interactions with cytochrome P450: effects on house fly CYP6A1 catalysis. - Insect Biochem Mol Biol 38: 1008-1015.

[41] Nafees, M., Jan, M. R., Khan, H. (2008): Pesticide Use in Swat Valley, Pakistan. - Mt Res Dev 28(3): 201-204.

[42] Nafees, M., Jan, M. R. (2009): Residues of cypermethrin and endosulfan in soils of Swat valley. - Soil \& Environ 28(2): 113-118.

[43] Nielsen, A. L., Shearer, P. W., Hamilton, G. C. (2008): Toxicity of insecticides to Halyomorpha halys (Hemiptera: Pentatomidae) using glass-vial bioassays. - J Econ Entomol 101: 1439-1442.

[44] Nishiwaki, H., Nakagawa, Y., Kuwamura, M., Sato, K., Akamatsu, M., Matsuda, K., Komai, K., Miyagawa, H. (2003): Correlations of the electrophysiological activity of neonicotinoids with their binding and insecticidal activities. - Pest Manag Sci 59: 10231030 . 
[45] Osano, O., Admiraal, W., Klamerc, H. J. C., Pastor, D., Bleeker, E. A. J. (2002): Comparative toxic and genotoxic effects of chloroacetanilides, formamidines and their degradation products on Vibrio fischeri and Chironomus riparius. - Environ Pollut 119: 195-202.

[46] Patar, A. A., Hassan, W. R. M., Hashim, N., Yusof, F. Z. M. (2015): Toxicity Effects of Malathion, Dichlorvos and Temephos on acetylcholinesterase in climbing perch (Anabas testudineus). - Adv Env Biol 9(21): 81-86.

[47] Poirier, D. G., Surgeoner, G. A. (1988): Evaluation of a field bioassaytechnique to predict the impact of aerial applications of forestryinsecticides on stream invertebrates. - Can Entomol 120: 627-637.

[48] Rubach, M. N., Ashauer, R., Maund, S. J., Baird, D. J., van den Brink, P. J. (2010): Toxicokinetic variation in 15 freshwater arthropod species exposed to the insecticide chlorpyrifos. - Environ Toxicol Chem 29(10): 2225-2234.

[49] Rubach, M. N., Baird, D. J., Boerwinkel, M.-C., Maund, S. J., Roessink, I., van den Brink, P. J. (2012): Species traits as predictors for intrinsic sensitivity of aquatic invertebrates to the insecticide chlorpyrifos. - Ecotoxicology 21: 2088-2101.

[50] Schroer, A. F. W., Belgers, J. D. M., Brock, T. C. M., Matser, M., Maund, S. J., van den Brink, P. J. (2004): Comparison of Laboratory Single Species and Field Population-Level Effects of the Pyrethroid Insecticide $\lambda$-Cyhalothrin on Freshwater Invertebrates. - Arch Environ Contam Toxicol 46: 324-335.

[51] Sirotkina, M., Lyagin, I., Efremenko, E. (2012): Hydrolysis of organophosphorus pesticides in soil: New opportunities with ecocompatible immobilized His6-OPH. - Int Biodeter \& Biodegr 68: 18-23.

[52] Stenersen, J. (2004): Chemical pesticides: mode of action and toxicology. - CRC Press, Boca Raton, Florida.

[53] Tien, C. J., Lin, M. C., Chiu, W. H., Chen, C. S. (2013): Biodegradation of carbamate pesticides by natural river biofilms in different seasons and their effects on biofilm community structure. - Environ Pollut 179: 95-104.

[54] Turusov, V., Rakitsky, V., Tomatis, L. (2002): Dichlorodiphenyltrichloroethane (DDT): Ubiquity, persistence, and risks. - Environ Health Perspec 110(2): 125-128.

[55] US EPA. (1996): Ecological Effects Test Guidelines: Aquatic Invertebrate Acute Toxicity Test, Freshwater Daphnids. - EPA 712-C-96-114.

[56] Vorkamp, K., Rigét, F. F. (2014): A review of new and current-use contaminants in the Arctic environment: Evidence of long-range transport and indications of bioaccumulation. - Chemosphere 111: 379-395.

[57] Wang, Y., Cang, T., Zhao, Z., Yu, R., Chen, L., Wu, C., Wang, Q. (2012): Comparative acute toxicity of twenty-four insecticides to earthworm, Eisenia fetida. - Ecotoxicol Environ Saf 79: 122-128.

[58] Wen, Z., Zhang, X., Zhang, Y. (2011): P450-mediated Insecticide Detoxification and Its Implication in Insecticide Efficacy. - In: Liu, T., Kang, L. (eds.) Recent Advances in Entomological Research: From Molecular Biology to Pest Management. Springer Heidelberg Dordrecht London New York, pp. 229-244.

[59] Werner, I., Moran, K. (2008): Effects of Pyrethroid Insecticides on Aquatic Organisms. Synthetic Pyrethroids, Chapter 14, pp. 310-334.

[60] Wheeler, M. W., Park, R. M., Bailer, A. J. (2006): Comparing median lethal concentrationvalues using confidence interval overlap or ratio tests. - Environ Toxicol Chem 25: 1441-1444.

[61] WHO. (1989): Dichlorvos. Environmental Health Criteria 79. - World Health Organisation, Geneva, Switzerland.

[62] Yousuf, M., Khan, M. J., Khaliq, A. (1996): Description of some final instar naiads (Libellulidae: Odonata) from Punjab and Sindh. - Pak Entomol 18(1-2): 17-23.

[63] Zacharia, J. T. (2011): Ecological Effects of Pesticides. - In: Stoytcheva, M. (ed.) Pesticides in the Modern World - Risks and Benefits. ISBN: 978-953-307-458-0. 